\title{
Keanekaragaman dan Kelimpahan Musuh Alami Bemisia tabaci (Gennadius) (Hemiptera: Aleyrodidae) pada Pertanaman Cabai Merah di Kecamatan Pakem, Kabupaten Sleman, Daerah Istimewa Yogyakarta
}

\author{
HENDRIVAL ${ }^{1)}$, PURNAMA HIDAYAT ${ }^{* 2)}$ DAN ALI NURMANSYAH ${ }^{2)}$ \\ ${ }^{1)}$ Program Studi Agroteknologi, Fakultas Pertanian, Universitas Malikussaleh, Jalan \\ Banda Aceh-Medan, Kampus UNIMAL Cot Tengku Nie, Reuleut, \\ Kabupaten Aceh Utara. \\ ${ }^{2)}$ Departemen Proteksi Tanaman, Fakultas Pertanian, Institut Pertanian Bogor, Jalan \\ Kamper Kampus IPB Darmaga, Bogor 16680
}

(diterima Maret 2011, disetujui Juni 2011)

\begin{abstract}
ABSTRAK
Keanekaragaman dan Kelimpahan Musuh Alami Bemisia tabaci (Gennadius) (Hemiptera: Aleyrodidae) pada Pertanaman Cabai Merah di Kecamatan Pakem, Kabupaten Sleman, Daerah Istimewa Yogyakarta. Penelitian tentang keanekaragaman dan kelimpahan musuh alami Bemisia tabaci di pertanaman cabai merah telah dilakukan di Kecamatan Pakem, Kabupaten Sleman, DIY selama musim kemarau Mei-Oktober 2009. Penelitian bertujuan untuk mempelajari keanekaragaman dan kelimpahan spesies parasitoid dan predator dari B. tabaci. Pengambilan sampel spesies parasitoid dan predator dilakukan dengan menggunakan nampan kuning, jaring serangga, pengamatan langsung pada tajuk tanaman, dan pengumpulan nimfa-nimfa $B$. tabaci. Keanekaragaman serangga dihitung menggunakan indeks keanekaragaman Shannon dan sebaran. Spesies predator yang ditemukan di pertanaman cabai merah adalah Harmonia octomaculata (Fabricius), Menochilus sexmaculata (Fabricius), Scymnus sp., Micraspis inops Mulsant, Coccinella sp., (Coleoptera: Coccinellidae), Paederus fuscipes Curtis (Coleoptera: Staphylinidae), Orius sp. (Hemiptera: Anthocoridae), Linyphiidae (Araneae), dan Syrphidae (Diptera). Parasitoid Eretmocerus sp. (Hymenoptera: Aphelinidae) ditemukan memarasit nimfa-nimfa B. tabaci mempunyai potensi yang baik untuk mengendalikan nimfa $B$. tabaci di pertanaman cabai merah.
\end{abstract}

KATA KUNCI: Bemisia tabaci, keanekaragaman, kelimpahan, parasitoid, predator

\section{ABSTRACT}

Natural Enemy Diversity and Abundance of Bemisia tabaci (Gennadius) (Hemiptera: Aleyrodidae) on Chili Pepper Fields in Sub-district of Pakem, District of Sleman, The Special Province of Yogyakarta. Research on natural enemies of Bemisia tabaci was conducted in the chili pepper fields in Sub-district of Pakem, District of Sleman, The Special Province of Yogyakarta during the dry season of May-October 2009. The aims of this research were to study the diversity

\footnotetext{
*Korespondensi:

Email: purhidayat@gmail.com
} 
and abundance of parasitoid and predator species associated with B. tabaci. Samplings of insect species were done using yellow pan trap, sweep net, direct observation of insects colonized young leaves, and collection of nymphs for $B$. tabaci. Measurement of insect diversity was calculated using Shannon's index diversity and Evenness index. Nine species of insect predator were identified, i.e. Harmonia octomaculata (Fabricius), Menochilus sexmaculata (Fabricius), Scymnus sp., Micraspis inops Mulsant, Coccinella sp. (Coleoptera: Coccinellidae), Paederus fuscipes Curtis (Coleoptera: Staphylinidae), Orius sp. (Hemiptera: Anthocoridae), Linyphiidae sp.1 (Araneae), and Syrphidae sp.1 (Diptera). Eretmocerus sp. (Hymenoptera: Aphelinidae) was the only parasitoid found in the nymphs $B$. tabaci collected and has the potential to control B. tabaci in the red pepper fields.

KEY WORDS: Bemisia tabaci, diversity, abundance, parasitoid, predator

\section{PENDAHULUAN}

Bemisia tabaci tergolong serangga polifag (Frohlich et al. 1999) dan tersebar luas di daerah tropik dan subtropik (Delatte et al. 2005). B. tabaci dapat menyebabkan terbentuknya bintik-bintik klorotik pada daun karena tusukan stiletnya dan penutupan stomata oleh embun madu yang dihasilkannya (Byrne \& Bellow 1991). B. tabaci merupakan serangga vektor yang dilaporkan mampu menularkan 110 jenis virus tanaman (Jones 2003). Salah satu virus yang ditularkan oleh $B$. tabaci adalah pepper yellow leaf curl virus (PepYLCV) yang menyebabkan penyakit daun keriting kuning cabai pada tanaman cabai merah (Tsai et al. 2006). Pertanaman cabai di Indonesia telah banyak dilaporkan terserang penyakit daun keriting kuning cabai yang disebabkan oleh PepYLCV (Sudiono \& Yasin 2006). Kehilangan hasil tanaman cabai merah akibat serangan B. tabaci dan penyakit keriting kuning cabai berkisar antara $20 \%$ sampai $100 \%$ (Setiawati et al.
2007). Upaya pengendalian yang umum dilakukan petani adalah penggunaan insektisida. Namun tindakan tersebut belum mampu menurunkan tingkat serangan dari $B$. tabaci, karena B. tabaci diduga berasal dari populasi yang telah resisten terhadap insektisida seperti golongan organofosfat, karbamat dan piretroid sintetik (De Barro 1995; Sugiyama 2005). Pengendalian hayati merupakan salah satu komponen pengendalian hama terpadu yang memiliki peranan dalam mencegah berkembangnya populasi $B$. tabaci yang telah resisten terhadap insektisida (Hoddle et al. 1998; Faria \& Wraight 2001). Musuh alami memiliki peranan penting dalam mengendalikan populasi B. tabaci yang telah resisten terhadap insektisida (Naranjo \& Ellsworth 2009).

Musuh alami hama $B$. tabaci berdasarkan fungsinya dikelompokkan menjadi predator dan parasitoid (Naranjo et al. 2002; Gerling et al. 2001), serta patogen (Gindin et al. 2000; Faria \& Wraight 2001). Kelompok predator B. tabaci meliputi famili Cocci- 
nellidae, Staphylinidae, Chrysopidae, Cecidomyiidae, Dolichopodidae, Syrphidae, Anthocoridae, Miridae, Nabidae, Phytoseiidae, dan Araneae (Castineiras 1995; Gerling et al. 2001; Naranjo et al. 2002). Parasitoid dari B. tabaci meliputi famili Aphelinidae dan Platygasteridae (Castineiras 1995; Gerling et al. 2001). Parasitoid famili Aphelinidae ordo Hymenoptera merupakan parasitoid yang potensial sebagai agen pengendali hayati dan banyak menyerang nimfa $B$. tabaci (Kirk et al. 2001) seperti dari genus Eretmocerus dan Encarsia (Gerling et al. 2001). Predator generalis dan parasitoid dari famili Aphelinidae seperti genus Eretmocerus dan Encarsia merupakan faktor pengatur dalam perkembangan populasi B. tabaci pada berbagai tanaman (Naranjo \& Ellsworth 2009). Informasi keanekaragaman dan kelimpahan musuh alami $B$. tabaci di pertanaman cabai merah masih sedikit, sedangkan peranan musuh alami sangat penting dalam mengatur keseimbangan populasi $B$. tabaci. Penelitian dilakukan untuk mengetahui keanekaragaman dan kelimpahan spesies parasitoid dan predator dari B. tabaci di pertanaman cabai merah.

\section{METODE PENELITIAN}

Penelitian dilaksanakan di Desa Harjobinangun, Kecamatan Pakem, Kabupaten Sleman, Daerah Istimewa Yogyakarta selama musim kemarau pada bulan Mei sampai Oktober 2009. Lokasi penelitian berada pada ketinggian 343 meter di atas permukaan laut dan terletak pada $07^{0} 40.814 \mathrm{LS}$ dan $110^{0} 242.51$ LU. Identifikasi serangga parasitoid dan predator dilakukan di Laboratorium Taksonomi Serangga, Institut Pertanian Bogor, Bogor.

\section{Persiapan Tanaman Cabai Merah.}

Penelitian dilaksanakan pada dua lahan masing-masing seluas $34 \mathrm{~m}$ x 12 $\mathrm{m}$, kedua lahan terletak secara terpisah dengan jarak $100 \mathrm{~m}$. Setiap lahan terdiri dari dua petak dengan panjang $16 \mathrm{~m}$ dan lebar $10 \mathrm{~m}$, sehingga terdapat empat petak sebagai ulangan. Setiap petak terdiri dari lima bedengan dengan ukuran panjang $15 \mathrm{~m}$, lebar 1 $\mathrm{m}$, dan tinggi $0,4 \mathrm{~m}$ serta jarak antar bedengan $0,5 \mathrm{~m}$. Varietas cabai merah yang digunakan adalah TM 999 yang merupakan varietas cabai yang umum ditanam oleh petani setempat. Bibit ditanam dengan jarak tanam $50 \mathrm{~cm}$ (dalam barisan) dan $60 \mathrm{~cm}$ (antarbaris) sehingga dalam bedengan terdapat 60 tanaman. Budidaya tanaman cabai merah mengikuti kebiasaan petani setempat, kecuali aplikasi insektisida dan penyiangan gulma yang tidak dilakukan selama pertumbuhan tanaman.

\section{Pengambilan Sampel.}

Pengamatan terhadap keanekaragaman dan kelimpahan spesies parasitoid dan predator dari B. tabaci dilakukan untuk menggambarkan jumlah 
spesies dan kelimpahan parasitoid dan predator di pertanaman cabai merah. Metode pengumpulan serangga dilakukan dengan berbagai cara tergantung pada jenis serangga dan habitatnya. Metode pengambilan sampel serangga dengan jaring ayun digunakan untuk menangkap serangga pada daun-daunan atau rumput-rumputan dan pada areal pertanaman yang berbentuk perdu seperti pertanaman cabai merah. Metode pengamatan langsung dilakukan terhadap spesies serangga, termasuk predator, yang terdapat pada tajuk tanaman. Pemerangkapan merupakan metode pengumpulan serangga dengan menggunakan perangkap seperti nampan kuning. Metode tersebut memiliki kemampuan memikat predator dan parasitoid secara fisik. Metode pengumpulan serangga, termasuk pada stadia nimfa-nimfa, dilakukan untuk mengetahui jenis-jenis parasitoid yang berasosiasi dengan serangga.

Metode pengambilan sampel spesies parasitoid dan predator dilakukan dengan menggunakan jaring ayun (sweep net), nampan kuning (yellow pan trap), pengamatan langsung, dan pengumpulan nimfa-nimfa $B$. tabaci dari tanaman cabai merah. Jaring ayun digunakan untuk pengambilan serangga pada tajuk tanaman atau gulma yang tumbuh di sekitar pertanaman cabai merah. Jaring ayun berbentuk kerucut, mulut jaring terbuat dari kawat melingkar (diameter $30 \mathrm{~cm}$ ) dan jaring terbuat dari kain kasa. Pengambilan dilakukan dengan mengayunkan jaring ke kiri dan ke kanan secara bolak-balik sebanyak 20 kali sambil berjalan. Perangkap nampan kuning ditempatkan pada tempat yang terbuka di pinggir petak pertanaman cabai merah. Untuk membunuh serangga yang hinggap pada nampan kuning, ke dalam nampan tersebut dimasukkan larutan air sabun untuk mengurangi tegangan permukaan, sehingga serangga yang masuk akan tenggelam dan mati. Pada setiap lahan pertanaman ditempatkan empat nampan kuning dan dibiarkan selama 24 jam.

Teknik pengamatan langsung pada tajuk tanaman juga dilakukan terhadap predator yang terdapat pada tajuk tanaman dengan mengamati delapan tanaman sampel per bedengan. Teknik pengamatan langsung juga dilakukan dengan mengumpulkan nimfa-nimfa $B$. tabaci yang terdapat pada daun dari tanaman cabai merah. Metode pengambilan sampel daun dilakukan secara acak untuk mengamati nimfa $B$. tabaci dari setiap tanaman sampel (delapan tanaman sampel per bedengan) dengan mengambil daun dari bagian atas, tengah, dan bawah dari tanaman. Pada tanaman sampel diambil enam daun (dua bagian atas, dua bagian tengah, dan dua bagian bawah). Daun-daun sampel disimpan di dalam kantung plastik untuk dilakukan pemeriksaan terhadap nimfa $B$. tabaci dengan 
menggunakan mikroskop stereo. Daundaun yang terdapat nimfa B. tabaci dimasukkan secara terpisah ke dalam cawan petri dan nimfa-nimfa tersebut dipelihara sampai menjadi stadia imago. Parasitoid-parasitoid yang muncul dikumpulkan dan dilakukan pencatatan terhadap jenis parasitoid yang muncul.

Serangga yang tertangkap disimpan dalam botol koleksi yang telah diisi dengan larutan alkohol $70 \%$ untuk selanjutnya diidentifikasi di Laboratorium Taksonomi Serangga, Institut Pertanian Bogor. Semua serangga yang diperoleh dipisahkan berdasarkan ordonya dan identifikasi dilakukan sampai tingkat takson spesies berdasarkan Goulet \& Huber (1993), Shepard et al. (1995), Evans \& Serra (2002), dan Evans (2009) serta dihitung jumlahnya. Pengelompokan serangga parasitoid dan predator dari B. tabaci dilakukan berdasarkan panduan dari Gerling et al. (2001). Pengamatan keanekaragaman dan kelimpahan spesies parasitoid dan predator dilakukan setiap minggu, mulai tanaman cabai merah berumur 1 sampai 16 minggu setelah tanam (MST).

\section{Analisis data.}

Keanekaragaman serangga dihitung menggunakan indeks keanekaragaman Shannon dan indeks kemerataan (Magurran 1996; Krebs 1999).

\section{HASIL DAN PEMBAHASAN} Keanekaragaman Spesies Predator dan Parasitoid

Jumlah spesies predator B. tabaci yang berhasil tertangkap berbeda-beda berdasarkan jenis perangkap yang digunakan. Setelah dilakukan identi fikasi, spesies-spesies predator tersebut adalah Linyphiidae sp. (Araneae), $H$. octomaculata, M. sexmaculata, Scymnus sp., M. inops, dan Coccinella sp. (Coleoptera: Coccinellidae), P. fusci pes (Coleoptera: Staphylinidae), Orius sp. (Hemiptera: Anthocoridae), dan Syrphidae sp.1 (Diptera). Indeks keanekaragaman Shanon $(\mathrm{H})$ dan indeks kemerataan (E) spesies predator lebih tinggi dijumpai pada metode pengamatan langsung pada tajuk tanaman yaitu 2,05 dan 0,93. Indeks $\mathrm{H}$ dan $\mathrm{E}$ spesies predator pada metode jaring ayun adalah 1,96 dan 0,89 serta metode nampan kuning adalah 1,24 dan 0,89 . Jumlah spesies parasitoid yang terkoleksi pada metode jaring ayun, nampan kuning, dan pengumpulan nimfa-nimfa $B$. tabaci adalah berturutturut 2 spesies, 2 spesies, dan 1 spesies. Spesies parasitoid tersebut adalah Encarsia sp. dan Eretmocerus sp. (Hymenoptera: Aphelinidae). Pada metode pengumpulan nimfa-nimfa $B$. tabaci dari daun cabai merah hanya terdapat satu spesies parasitoid yaitu Eretmocerus sp. Jumlah spesies parasitoid lebih tinggi pada metode jaring ayun dan nampan kuning dibandingkan metode pengumpulan nimfa-nimfa $B$. 
tabaci. Keanekaragaman dan sebaran spesies parasitoid lebih tinggi dijumpai pada metode jaring ayun yaitu 0,66 dan 0,96 dibandingkan metode nampan kuning (Tabel 1).

Perolehan serangga predator dari berbagai metode pengumpulan serangga menunjukkan bahwa kelompok predator dari famili Coccinellidae memiliki jumlah spesies paling tinggi dibandingkan spesies predator dari famili lainnya (Tabel 1). Famili Coccinellidae diketahui sebagai predator berbagai jenis serangga hama dan lebih memangsa kutu daun. Walaupun demikian dilaporkan oleh Gerling et al. (2001) bahwa spesies predator Coccinellidae merupakan predator oligofag yang banyak memangsa nimfa $B$. tabaci pada tanaman kapas dan Dialeurodes citri pada tanaman jeruk. Dinyatakan oleh Cohen \& Brummett (1997) bahwa kisaran mangsa predator dari B. tabaci dapat dipengaruhi oleh kualitas nutrisi mangsa; pada saat populasi B. tabaci menurun, banyak spesies predator mencari mangsa yang sesuai untuk perkembangan dan reproduksinya misalnya dengan memangsa kutu daun. Spesies predator yang memiliki kisaran mangsa yang luas dapat berada pada tanaman pada waktu yang lebih lama dan secara efektif mengatur peledakan populasi $B$. tabaci.

Serangga predator lainnya yang dijumpai dari berbagai metode pengambilan sampel adalah famili An- thocoridae, Syrphidae, dan Staphylinidae. Famili Anthocoridae merupakan predator penting dalam pengendalian hayati dan memangsa thrips dan telur serangga hama seperti Ostrinia nubilalis (Driesche \& Bellows 1996), kutu daun dan tungau (Bugg et al. 2008). Serangga pradewasa dari famili Syrphidae merupakan predator yang memangsa kutu daun dan serangga hama lainnya (Bugg et al. 2008); sementara imago dari famili Syrphidae berperan sebagai polinator pada tanaman sayuran dan buah-buahan seperti famili Asteraceae, Brassicaceae, dan Rosaceae (Ghahari et al. 2008). Paederus fuscipes merupakan predator yang juga memangsa $B$. tabaci (Gerling et al. 2001). Larva P. fuscipes hidup dan mencari mangsa pada permukaan tanah terutama pada daerah dengan kelembaban tinggi dan banyak mengandung sisa-sisa tanaman. Imago $P$. fuscipes lebih sering berasosiasi dengan tajuk tanaman untuk mencari mangsa.

Parasitoid Encarsia sp. dan Eretmocerus sp. merupakan parasitoid utama dari B. tabaci seperti dilaporkan oleh Castineiras (1995) dan Gerling et al. (2001). Dari hasil pengumpulan nimfa-nimfa $B$. tabaci, hanya parasitoid Eretmocerus sp. yang ditemukan memarasit nimfa B. tabaci dan parasitoid Encarsia sp. tidak ditemukan memarasit nimfa $B$. tabaci. Hasil pengamatan di pertanaman cabai merah menunjukkan bahwa nimfa $B$. 
궁 Tabel 1 Jumlah ordo (O), famili (F), spesies (S), jumlah individu (N), indeks keanekaragaman Shannon $\left(\mathrm{H}^{\prime}\right)$, dan indeks kemerataan $(\mathrm{E})$ predator dan parasitoid dari B. tabaci pada setiap metode pengambilan sampel di pertanaman cabai merah pada musim kemarau Juni sampai Oktober tahun 2009 di Desa Harjobinangun, Kecamatan Pakem, Kabupaten Sleman, DIY

\begin{tabular}{|c|c|c|c|c|c|c|c|c|}
\hline \multirow[b]{2}{*}{ No. } & \multirow[b]{2}{*}{$\begin{array}{l}\text { Kelompok } \\
\text { fungsional }\end{array}$} & \multirow[b]{2}{*}{ Ordo } & \multirow[b]{2}{*}{ Famili } & \multirow[b]{2}{*}{ Spesies } & \multicolumn{4}{|c|}{ "Metode pengumpulan } \\
\hline & & & & & Jaring ayun & $\begin{array}{l}\text { Nampan } \\
\text { kuning }\end{array}$ & $\begin{array}{c}\text { Pengamatan langsung } \\
\text { pada tajuk tanaman }\end{array}$ & $\begin{array}{c}\text { Pengumpulan } \\
\text { nimfa-nimfa } B \text {. } \\
\text { tabaci }\end{array}$ \\
\hline 1 & Predator & Araneae & Linyphiidae & Linyphiidae sp. 1 & 96 & & 202 & $-^{\mathrm{a}}$ \\
\hline 2 & Predator & Coleoptera & Coccinellidae & H. octomaculata & 159 & 8 & 186 & - \\
\hline 3 & Predator & Coleoptera & Coccinellidae & M. sexmaculata & 308 & 24 & 306 & - \\
\hline 4 & Predator & Coleoptera & Coccinellidae & Scymnus sp. & 46 & & 81 & - \\
\hline 5 & Predator & Coleoptera & Coccinellidae & Micraspis inops & 225 & 6 & 141 & - \\
\hline 6 & Predator & Coleoptera & Coccinellidae & Coccinella sp. & 202 & & 166 & - \\
\hline 7 & Predator & Coleoptera & Staphylinidae & P. fuscipes & 261 & 17 & 345 & - \\
\hline 8 & Predator & Hemiptera & Anthocoridae & Orius sp. & 21 & & 40 & - \\
\hline 9 & Predator & Diptera & Syrphidae & Syrphidae sp. 1 & 53 & & 110 & - \\
\hline & Jumlah ordo & & & & 4 & 1 & 4 & - \\
\hline & Jumlah famili & & & & 5 & 2 & 5 & - \\
\hline & Jumlah spesies & & & & 9 & 4 & 9 & - \\
\hline & Jumlah individu & & & & 1371 & 55 & 1577 & - \\
\hline & $\mathrm{H}^{\prime}$ & & & & 1,9697 & 1,2468 & 2,0502 & $\mathrm{tt}^{\mathrm{b}}$ \\
\hline & $\mathrm{E}$ & & & & 0,8964 & 0,8994 & 0,9331 & $\mathrm{tt}$ \\
\hline 10 & Parasitoid & Hymenoptera & Aphelinidae & Encarsia $\mathrm{sp}$. & 70 & 92 & $-^{c}$ & \\
\hline 11 & Parasitoid & Hymenoptera & Aphelinidae & Eretmocerus sp. & 109 & 270 & - & 695 \\
\hline & Jumlah ordo & & & & 1 & 1 & - & 1 \\
\hline & Jumlah famili & & & & 1 & 1 & - & 1 \\
\hline & Jumlah spesies & & & & 2 & 2 & - & 1 \\
\hline & Jumlah individu & & & & 179 & 362 & - & 695 \\
\hline & $\mathrm{H}^{\prime}$ & & & & 0,6692 & 0,5668 & - & $\mathrm{tt}$ \\
\hline & $\mathrm{E}$ & & & & 0,9654 & 0,8177 & - & $\mathrm{tt}$ \\
\hline
\end{tabular}


tabaci mulai ditemukan terparasit oleh Eretmocerus sp. pada 2 MST dengan tingkat parasitisasi mencapai $12,9 \%$. Selama pertumbuhan tanaman cabai merah terjadi empat kali peningkatan parasitisasi parasitoid Eretmocerus sp. yaitu pada 5 MST, 7 MST, 10 MST, dan 13 MST dengan tingkat parasitisasi berturut-turut mencapai $39,1 \%$; 41,1\%; 55,5\%; dan 57,6\%. (Gambar 1). Proses parasitisasi Eretmocerus sp. di pertanaman cabai merah dipengaruhi oleh keragaman vegetasi. Selama pertumbuhan tanaman cabai merah tidak dilakukan penyiangan gulma, sehingga banyak dijumpai gulma yang tumbuh di bedengan pertanaman. Ekosistem yang demikian dapat mendukung keberadaan musuh alami seperti parasitoid (Smith et al. 1997). Spesiesspesies gulma yang tumbuh di per- tanaman budidaya berperan sebagai tempat berlindung imago parasitoid dan menyediakan inang alternatif musuh alami seperti menurut Norris \& Kogan (2005).

Spesies gulma yang menjadi inang B. tabaci dapat bermanfaat dalam menyediakan inang alternatif dan konservasi parasitoid Eretmocerus sp. di pertanaman cabai merah. Castineiras (1995), Gerling et al. (2001), dan Kirk et al. (2001), menyatakan bahwa genus Eretmocerus merupakan parasitoid $B$. tabaci yang telah banyak digunakan untuk pengendalian hayati $B$. tabaci.

Parasitoid Eretmocerus sp. umumnya memarasit nimfa $B$. tabaci instar ke-2 sampai ke-4, namun preferensinya lebih tinggi pada nimfa instar ke-2 (Gerling et al. 2001).

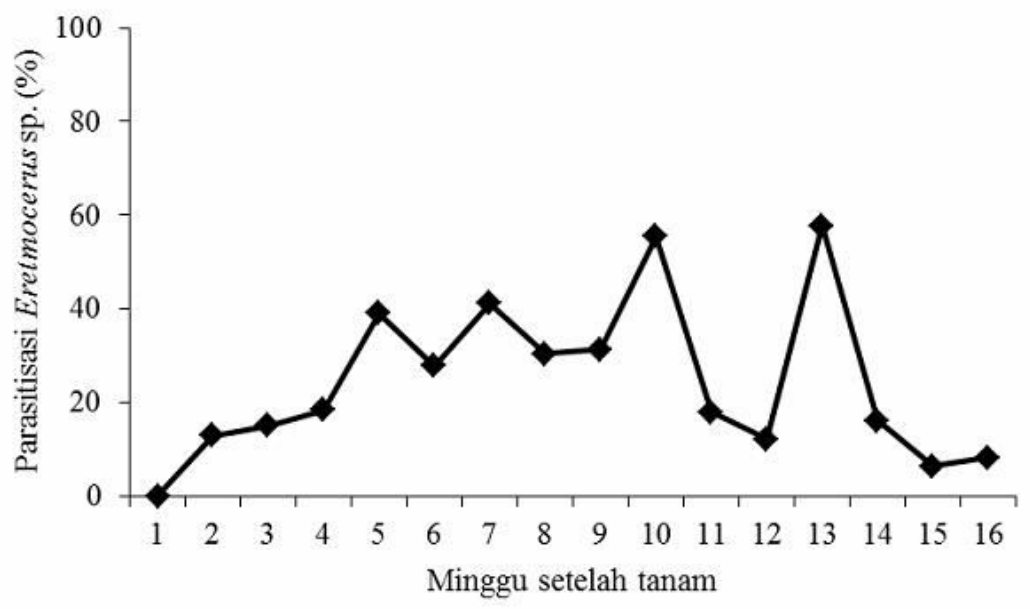

Gambar 1. Perkembangan tingkat parasitisasi parasitoid Eretmocerus sp. pada nimfa $B$. tabaci selama pertumbuhan tanaman cabai merah pada musim kemarau Juni sampai Oktober tahun 2009 di Desa Harjobinangun, Kecamatan Pakem, Kabupaten Sleman, DIY 
Parasitoid Eretmocerus sp. dapat menyelesaikan siklus hidupnya sampai fase imago pada satu nimfa $B$. tabaci atau bersifat soliter. Seperti yang dikatakan oleh Driesche \& Bellows (1996) dan Hajek (2004), suatu parasitoid yang perkembangan hidupnya terjadi pada satu tubuh inang disebut parasitoid soliter dan bersifat endoparasitoid. Selanjutnya Zolnerowich \& Rose (2008) menyatakan bahwa parasitoid Eretmocerus sp. merupakan parasitoid soliter dan endoparasitoid yang memarasit nimfa $B$. tabaci instar kedua dan imago parasitoid muncul dari nimfa instar ke-4 yang telah mati. Genus Eretmocerus memiliki 65 spesies dan semua spesies diketahui sebagai parasitoid primer kutu kebul dan banyak diantaranya yang belum diketahui spesiesnya memarasit $B$. tabaci (Zolnerowich \& Rose 2008). Eretmocerus eremicus diketahui efektif menekan populasi B. tabaci pada tanaman tomat, cabai, dan melon (Gerling et al. 2001; Bellamy et al. 2004). Eretmocerus mundus diketahui dapat memarasit nimfa $B$. tabaci pada tanaman cabai, melon, dan lada di Argentina (López \& Andorno 2009).

\section{Kelimpahan Spesies Predator dan Parasitoid}

Serangga-serangga predator yang berhasil dikumpulkan dari pertanaman cabai merah telah diidentifikasi berdasarkan publikasi Gerling et al. (2001). Serangga predator tersebut terdiri atas spesies-spesies dari ordo Co- leoptera famili Coccinellidae yaitu Harmonia octomaculata, Menochilus sexmaculata, Scymnus sp., Micraspis inops, dan Coccinella sp., serta famili Staphylinidae yaitu Paederus fuscipes; ordo Hemiptera famili Anthocoridae yaitu Orius sp.; ordo Diptera famili Syrphidae; dan ordo Areneae yaitu Linyphiidae. Spesies predator dari $B$. tabaci dengan kelimpahan yang paling tinggi adalah $M$. sexmaculata dan $P$. fuscipes dengan nilai kelimpahan berturut-turut yaitu $21,2 \%$ dan $20,7 \%$; sedangkan spesies predator dengan nilai kelimpahan paling rendah adalah Orius sp. (2,1\%) (Gambar 2). Predator M. sexmaculata merupakan predator yang sangat potensial dalam pengendalian hayati hama tanaman seperti $B$. tabaci. Dilaporkan oleh Muharam \& Setiawati (2007) bahwa predator $M$. sexmaculata mampu memangsa $B$. tabaci sebanyak 51,5 ekor selama periode 24 jam. Selanjutnya, Hidayat et al. (2009) menyatakan bahwa berdasarkan distribusi, kelimpahan dan uji efektivitas, diketahui bahwa spesies predator yang berpotensi sebagai agens hayati B. tabaci adalah $M$. sexmaculata dan M. inops.

Kelompok fungsional parasitoid yang berhasil diperoleh dari pertanaman cabai merah di Pakem, Sleman, DIY terdiri dari ordo Hymenoptera famili Aphelinidae yaitu Encarsia sp. dan Eretmocerus sp. Kelimpahan spesies parasitoid Eretmocerus sp. $(89,9 \%)$ lebih tinggi dibandingkan 
Encarsia sp. (13,1\%) (Gambar 2). Parasitoid Eretmocerus sp. yang lebih dominan dibandingkan Encarsia sp. di pertanaman cabai merah diduga terjadi karena adanya faktor kompetisi terhadap inang dari kedua parasitoid tersebut. Parasitoid Eretmocerus sp. bersifat oligofag yang dapat memarasit spesies kutu kebul lainnya (Evans \& Serra 2002), sehingga menyebabkan parasitoid Eretmocerus sp. mudah dijumpai pada daerah dengan populasi B. tabaci yang melimpah. Parasitoid Encarsia sp. diketahui lebih banyak memarasit kutu kebul Trialeurodes vaporariorum, Aleurocanthus woglumi, dan Dialeurodes citri dibandingkan dengan B. tabaci (Evans 1997; Gerling et al. 2001), sehingga kelimpahan parasitoid Eretmocerus sp. lebih tinggi dibandingkan Encarsia sp. di pertanaman cabai merah.

Keanekaragaman musuh alami perlu dipertahankan melalui perlakuan konservasi sehingga pemanfaatan musuh alami dapat berlangsung secara berkelanjutan pada waktu sekarang dan waktu yang akan datang. Driesche \& Bellows (1996) menjelaskan kegiatan konservasi musuh alami meliputi (1) penggunaan pestisida secara terbatas dan selektif, (2) melestarikan spesies-

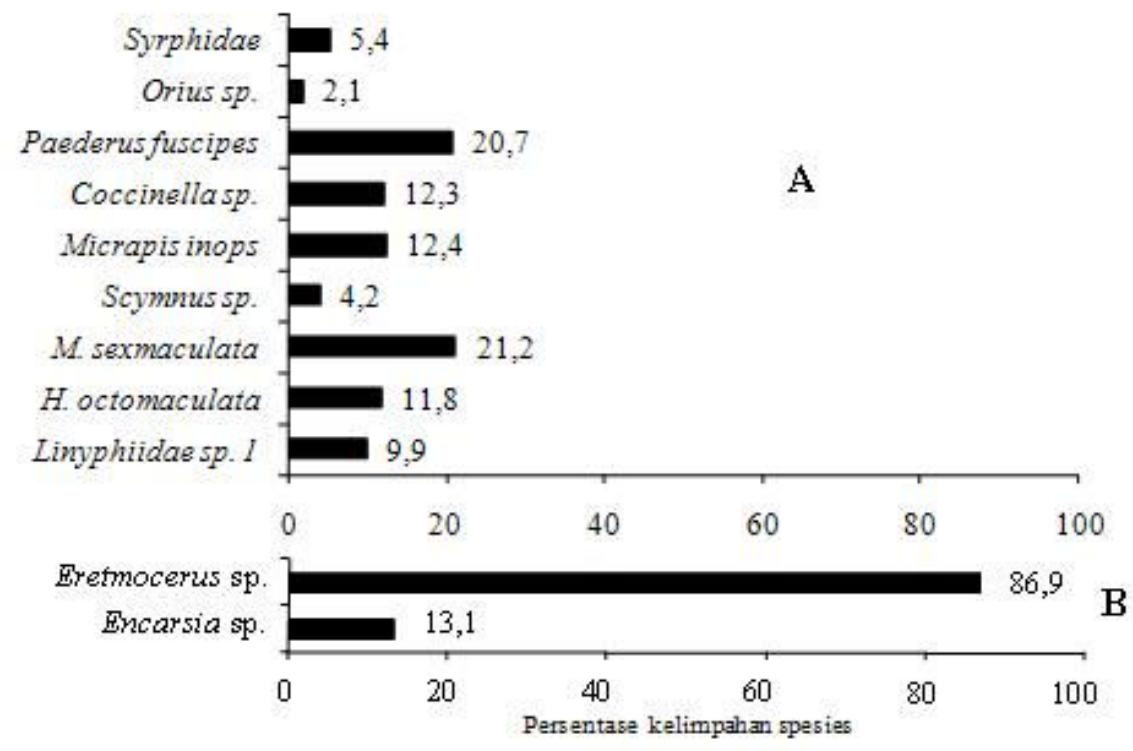

Gambar 2 Persentase kelimpahan spesies predator (A) dan parasitoid (B) $B$. tabaci dari empat metode pengumpulan serangga yaitu metode jaring ayun, nampan kuning, pengamatan langsung pada tajuk tanaman, dan pengumpulan nimfa-nimfa $B$. tabaci pada tanaman cabai merah selama musim kemarau Juni sampai Oktober tahun 2009 di Desa Harjobinangun, Kecamatan Pakem, Kabupaten Sleman, DIY. 
spesies gulma yang mendukung inang parasitoid atau mangsa alternatif predator, (3) memfasilitasi perpindahan musuh alami, dan (4) memodifikasi sistem budidaya tanaman. Konservasi musuh alami pada area yang berdekatan dapat meningkatkan keberadaan parasitoid dan predator yang dapat membantu menurunkan populasi $B$. tabaci dalam jangka panjang. Pengendalian hayati $B$. tabaci dengan parasitoid dan predator merupakan kunci strategis potensial yang sebagian besar belum direalisasikan pada tanaman budidaya (Naranjo 2001).

\section{KESIMPULAN}

Pengendalian hayati B. tabaci di pertanaman cabai merah mempersyaratkan faktor keanekaragaman parasitoid dan predator untuk mencapai kestabilan komunitas. Seranggaserangga predator yang bersifat oligofag seperti famili Coccinellidae $(H$. octomaculata, M. sexmaculata, Scymnus sp., M. inops, dan Coccinella sp.) dan Syrphidae serta bersifat generalis seperti famili Anthocoridae (Orius sp.) diperlukan untuk mengendalikan $B$. tabaci yang berasosiasi dengan tanaman cabai merah. Predator tersebut diharapkan dapat berperan sebagai pengatur populasi hama sehingga tidak terjadi peledakan populasi hama. Parasitoid Eretmocerus sp. merupakan parasitoid kutu kebul yang berpotensi untuk mengendalikan $B$. tabaci di pertanaman cabai merah.

\section{UCAPAN TERIMAKASIH}

Penelitian ini terlaksana berkat dukungan dana dari Project ACIARAVRDC Chilli IDM tahun 2009 melalui Dr. Ir. Sri Hendrastuti Hidayat, M.Sc, Institut Pertanian Bogor, Bogor. Ucapan terima kasih disampaikan kepada Ir. Bagus Kukuh Udiarto, M.P., Pak Ngadimin, dan Pak Mardi yang telah membantu pelaksanaan penelitian.

\section{DAFTAR PUSTAKA}

Bellamy DE. Asplen MK, \& Byrne DN. 2004. Impact of Eretmocerus eremicus (Hymenoptera: Aphelinidae) on open-field $\mathrm{Be}$ misia tabaci (Hemiptera: Aleyrodidae) populations. Biol. Control 29:227-234.

Bugg RL, Colfer RG, Chaney WE, Smith HA, \& CannonJ. 2008. Flower flies (Syrphidae) and other biological control agents for aphids in vegetable crops. ARN Publication 8285:1-25.

Byrne DN. \& Bellows Jr. TS. 1991. Whitefly biology. Ann. Rev. Entomol. 36:431-457.

Castineiras A. 1995. Natural enemies of Bemisia tabaci (Homoptera: Aleyrodidae) in Cuba. Florida Entomologist 78(3):538-540.

Cohen AC. \& Brummett DL. 1997. The non-abundant nutrient (NAN) concept as a determinant of predator-prey fitness. Entomophaga 42:85-91.

De Barro PJ. 1995. Bemisia tabaci biotypes: a review of itsbiology, distribution and control. Com- 
monwealth Scientificand Industrial Research Organization Technical Paper 33.

Delatte H, Reynaud B, Granier M, Thornary L, Lett JM, Goldbach, R, \& Peterschmitt M. 2005. A new silverleaf-inducing biotype Ms of Bemisia tabaci (Hemiptera: Aleyrodidae) indigenous to the islands of the southwest Indian Ocean. Bull. Entomol. Res. 95:29-35.

Driesche RG van. \& Bellows Jr.TS. 1996. Biological Control. London:Chapman \& Hall.

Evans GA. \& Serra CA. 2002. Parasitoids associated with whiteflies (Homoptera: Aleyrodidae) in Hispaniola and descriptions of two new species of Encarsia (Hymenoptera: Aphelinidae). J. Hym. Res. 11(2):197-212.

Evans GA. 1997. A new Encarsia (Hymenoptera: Aphelinidae) species reared from the Bemisia tabaci complex (Homoptera: Aleyrodidae). Florida Entomologist 80(1):24-27.

Evans GA. 2009. Key to parasitoid genera associated with whiteflies (Aleyrodidae). http://www.sel. barc.usda.gov:8080/1WF/couplet 1.html [diakses 14 Desember 2009].

Faria M. \& Wraight SP. 2001. Biologi cal control of Bemisia tabaci with fungi. Crop Prot. 20:767778.

Frohlich DR, Torres-Jerez I, Bedford ID, Markham PG, \& Brown JK. 1999. A phylogeographical analysis of the Bemisia tabaci species complex based on mitochondrial DNA markers. Mol. Ecol. 8:1683-1691.

Gerling D, Alomar O, \& Arno J. 2001. Biological control of Bemisia tabaci using predators and parasitoids. Crop Prot. 20:779-799.

Ghahari H, Hayat R, Tabari M, \& Ostovan H. 2008. Hover flies (Diptera: Syrphidae) from rice fields and around grasslands of northern Iran. Mun. Ent. Zool. 3(3):275-284.

Gindin G, Geschtovt NU, Raccah B, \& Barash I. 2000. Pathogenicity of Verticillium lecanii to different develop-mental stages of the silverleaf whitefly, Bemisia argentifolii. Phytoparasitica 28(3): 229-239.

Goulet H. \& Huber JT, editor. 1993. Hymenoptera of the World: An Identification Guide to Families. Canada: Canada Communication Group Publishing.

Hajek AN. 2004. Natural Enemies: An Introduction to Biological Control. London: Cambridge University Press.

Hidayat P, Udiarto BK, Setiawati W, \& Murtiningsih RRR. 2009. Strategi pemanfaatan musuh alami dalam pengendalian Bemisia tabaci (Gennadius) (Hemiptera: Aleyrodidae) sebagai vektor virus kuning pada pertanaman cabai merah [laporan penelitian KKP3T]. Bogor: Institut Pertanian Bogor.

Hoddle MS, van Driesche RG, Sanderson JP. \& Minkenberg OPJM. 1998. Biological control of Bemisia argentifolii (Hemiptera: 
Aleyrodidae) on poinsettia with inundative releases of Eretmocerus eremicus (Hymenoptera: Aphelinidae): do release rates affect parasitism? Bull. Entomol. Res. 88:47-58.

Jones D. 2003. Plant viruses transmitted by whiteflies. Eurp. J. Plant Pathol. 109:197-221.

Kirk AA, Lacey LA, \& Goolsby JA. 2001. Classical biological control of Bemisia and successful integration of management strategies in the United States. in: Harris, K.F., O.P. Smith, \& J.E. Duffus (ed.), Virus-Insect-Plant Interactions. London: Academic Press. p 309-329.

Krebs CJ. 1999. Ecological Metodology. $2^{\text {rd }}$ ed. New York: An Imprint of Addison Wesley Longman, Inc.

López SN. \& Andorno AV. 2009. Evaluation of the local population of Eretmocerus mundus (Hymenoptera: Aphelinidae) for biological control of Bemisia tabaci biotype B (Hemiptera: Aleyrodidae) in greenhouse peppers in Argentina. Biol. Control 50:317-323.

Magurran AE. 1996. Ecologycal Diversity and Its Measurement. London: Chapman and Hall.

Muharam A \& Setiawati W. 2007. Teknik perbanyakan masal predator Menochilus sexmaculatus pengendali serangga Bemisia tabaci vector virus kuning pada tanaman cabai. J. Hort. 17(4):365-373.

Naranjo SE. 2001. Conservation andevaluation of natural enemies in
IPM systems for Bemisia tabaci. Crop Prot.. 20:835-852.

Naranjo SE, Ellsworth PC, Chu CC, \& Henneberry TJ. 2002. Conservation of predatory arthropods in cotton: role of action thresholds for Bemisia tabaci (Homoptera: Aleyrodidae). J. Econ. Entomol. 95(4):682-691.

Naranjo SE \& Ellsworth PC. 2009. The contribution of conservation biological control to integrated control of Bemisia tabaci in cotton. Biol. Control 51:458-470.

Norris RF \& Kogan M. 2005. Ecology of interaction between weeds and arthtropods. Ann. Rev. Entomol. 50:479-503.

Setiawati W, Udiarto BK \& Soetiarso TA. 2007. Selektivitas beberapa insektisida terhadap hama kutu kebul (Bemisia tabaci Genn.) dan predator Menochilus sexmacula tus Fabr. J. Hort. 17(2): 168-174.

Shepard BM, Barrion AT \& Litsinger J. A. 1995. Serangga, Laba-laba, dan Patogen yang Membantu. Untung $\mathrm{K}$, Wirjosuhardjo S, penerjemah. Jakarta: Program Nasional Pengendalian Hama Terpadu, Bappenas. Terjemahan dari: Helpful Insects, Spiders, and Pathogens.

Smith JW Jr., Wiedenmann RN., \& Gilstrap FE. 1997. Challenges and opportunities for biological control in Ephemeral crop habitats: an Overview. Biol. Control 10: 2-3.

Sudiono \& Yasin N. 2006. Karakteristik kutu kebul (Bemisia tabaci) sebagai vektor virus gemini 
dengan teknik PCR-RAPD. $J$. HPT. Tropika 6(2):113-119.

Sugiyama K. 2005. Management of whitefly for commercial tomato production in greenhouses in Shizuoka, Japan. in: Ku, T.Y. \& Wang C.L, editor. Proc. of the International Seminar on White fly Management and Control Strategy. Taichung, Taiwan, Oct 3-8, 2005. Taichung, Taiwan. $\mathrm{p}$ 81-91.
Tsai JH. Wang K. 1996. Development and reproduction of Bemisia argentifolii (Homoptera: Aleyrodidae) on five host plant. $J$. Environ. Entomol. 25:810-816.

Zolnerowich G, Rose M. 2008. The genus Eretmocerus. in: Gould J, Hoelmer K. \& Goolsby J, (ed.). Classical Biological Control of Bemisia tabaci in the United States-A Review of Interagency Research and Implementation. Netherlands: Springer. p 89-109. 